\title{
Impact of Small and Medium-Sized Enterprises (SMEs) on the Sustainable Development in Yemen during the Period from 2000 to 2018: An Empirical Study
}

\author{
Shagea GHALEB ${ }^{1,2} \odot$, Ekrem GÜL ${ }^{3} \odot$
}

\begin{abstract}
This study aims to identify the impact of small and mediumsized enterprises on Yemen's sustainable development, and the role these enterprises play at the levels of the industrial sector and the economy as a whole. This is done through descriptive and statistical analysis of collected data for exhibiting the progression of the most significant indicators of sustainable development in Yemen in all its aspects, economic, social, environmental, and institutional, and the progression of small and medium-sized enterprises, their role and contribution to employment, production, and the value-added. The study follows the partial least squares structural equation modeling (PLS-SEM) for analyzing the data of the selected variables during the period from 2000 to 2018 using the statistical program SmartPLS3. The study findings show that, though indicators of sustainable development were low, the small and mediumsized enterprises had a favorable effect on Yemen's sustainable development during the period selected for this study.
\end{abstract}

Keywords: Sustainable development, Economic dimension, Social dimension, Environmental dimension, Institutional dimension, SMEs, PLS-SEM, Yemen
DOI: 10.26650/ISTJECON2021-1004194

'Lecturer, Faculty Administrative Sciences, Department of Economics, Taiz University, Taiz, Yemen

2PhD Student, Institute of Social Sciences, Department of Economics, Sakarya University, Sakarya, Turkey

${ }^{3}$ Prof. Dr., Faculty of Political Sciences, Department of Economics, Sakarya University, Sakarya, Turkey

ORCID: S.G. 0000-0002-6384-4599; E.G. 0000-0002-2607-9066

\section{Corresponding author:}

Shagea GHALEB,

Institute of Social Sciences, Department of

Economics, Sakarya University, Sakarya, Turkey

E-mail: Shagea.gh@taiz.edu.ye

Submitted: 04.10 .2021

Accepted: 23.01 .2022

Citation: Ghaleb, S., \& Gül, E. Impact of small and medium-sized enterprises (SMEs) on the sustainable development in Yemen during the period from 2000 to 2018: An empirical study. Istanbul iktisat Dergisi - Istanbul Journal of Economics, 72(1), $x$-x.

https://doi.org/10.26650/ISTJECON2021-1004194 


\section{Introduction}

Encouraging the development of small and medium-sized enterprises (SMEs) is one of the key sources of economic development process all over the world. Particularly, these enterprises have greater importance in developing countries since they are more appropriate for the nature of the economies of those countries (Mukwena, 2016), including Yemen. They are widespread and characterized by their lower costs and growing employment, thus enabling them to develop and invest small savings. Consequently, they actively contribute to the reduction of poverty and unemployment which are some of the main challenges facing societies in developing countries. In addition, these small and medium-sized enterprises are a key factor that can make the economy more productive, generate income and the value-added, promote export subsidy, and produce commodities at affordable prices. They also serve to enhance renovation and novelty and develop entrepreneurship and business skills in society (Hallberg, 2000).

Yemen, as a developing country, has suffered a significant decrease in sustainable development indicators economically, socially, environmentally, and institutionally, particularly in recent years in which the political unrest and civil war in the country have disrupted a lot of pioneering economic sectors such as the oil and gas sector. The dearth of large projects, the limitation of their employment capacities, and the modest role they play in reducing poverty all make way for the small and medium-sized enterprises to play a greater part in the sustainable development in Yemen. This is why the present study seeks to identify the impact of small and medium-sized enterprises on the development process in Yemen during the aforesaid period.

The main problem of the present study lies in the mismatch between the objectives of sustainable development and investment in the field of small and medium-sized enterprises in Yemen, which are seen as being in conflict with each other in the achievement of common objectives. Being the mainstay of development, these small and medium-sized enterprises make a vital contribution to employment creation and to raising per capita income and GDP which should 
favorably reflect the continued growth of sustainable development as a whole. The present study attempts to answer a major question related to the role, importance, and impact of small and medium-sized enterprises on sustainable development. It also attempts to raise the question of whether or not an investment in small and medium-sized enterprises promotes the improvement of sustainable development indicators in Yemen. The objectives of this study can be listed as follows:

- Analyze the progress of the key indicators selected for sustainable development in Yemen during the period 2000-2018 at various levels, economically, socially, environmentally, and institutionally.

- Analyze the progress in the development of small and medium-sized enterprises through a number of indicators and identify the role these enterprises play in the employment creation and contribution to the value-added and to GDP of the industrial sector and the economy as a whole.

- Provide an exploratory model to identify the impact of small and mediumsized enterprises on sustainable development in Yemen.

\section{Literature Review}

A study by Zaidan (2006) investigating the importance of activating the role of small and medium-sized enterprises in the economic and social development process in Syria during the period 1970-2001 found that the economic surplus achieved by the small and medium-sized enterprises constituted the largest percentage of the surplus achieved by the private industrial sector. It was also found that small and medium-sized enterprises contributed to the attraction of more new arrivals to the labor market. As regards the economic efficiency of small and medium-sized enterprises, it was shown that they were appropriate for the Syrian economy and proved to be superior to large projects. It is also understood that, in the context of globalization and market economy, small and medium-sized enterprises face challenges of intensive competition, thus resulting in some of these enterprises being at risk of collapse. This, however, may not stop them from surviving not only in the local market but also in such a competitive global market. 
Çatal (2007) considered the importance and role of small and medium-sized enterprises in the economy of Turkey as a proportion of total enterprises of the industrial sector, their share in the total enterprises of the economy, their contribution to employment creation, the value-added, foreign trade, vitality of the economy, flexibility and creativity promotion, finance, and to the acceleration of regional development. The study found that small and medium-sized enterprises have an important role in the regional development process, and in the exploration of the country's potentials for entrepreneurship, besides the role they play in eliminating unemployment.

Safiriyu and Njogo (2012) aimed to identify the impact of small and mediumsized enterprises on employment creation and on the role they play in the Nigerian sustainable development through two hypotheses. First, a relationship exists between small and medium-sized enterprises and employment creation. Second, a relationship exists between small and medium-sized enterprises and sustainable development. From data and questionnaire analysis, it was found that there was, on the one hand, a direct correlation between small and medium-sized enterprises and employment creation and that, on the other hand, a direct correlation existed between small and medium-sized enterprises and sustainable development.

Taiwo, Ayodeji, and Yusuf (2012) aimed to identify the role played by small and medium-sized enterprises in the economic growth and development of Nigeria through a comprehensive survey of more than 200 projects registered with the government of Nigeria. It was hypothesized that there was a statistically significant relationship between small and medium-sized enterprises and Nigerian economic growth and development. From the descriptive and quantitative analysis and the test of correlation coefficient reaching (0.88), it was affirmed that a statistically significant relationship exists between small and medium-sized enterprises and the economic growth and development of Nigeria.

Sharafat, Rashid, and Khan (2014) aimed to investigate the impact of small and medium-sized enterprises on poverty and development in Pakistan through a 
descriptive and empirical study on a number of variables such as inflation, health expenditure, population growth rate, inequality in income distribution, and the number of the poor during the period 1972-2007. For this purpose, the study used the autoregressive model of ordinary least squares (OLS). The study found that small and medium-sized enterprises play a very important part in economic growth, employment creation, and reduction of poverty in the country.

Gökçek and Karakaya (2020) aimed to examine the relationship between the economic activities of enterprises registered with the government of Turkey on both of GDP and GDP per capita during the period 2009-2018. The study analyzed data by using the statistical program SPSS. The findings showed that there was a favorable relationship between these enterprises and GDP increase. It was determined that such a statistical relationship cannot be obtained in a short time, and there was a favorable relationship between these enterprises and GDP per capita. This relationship, however, was relatively weak due to, as the study stated, the downturn in the global economy.

\section{Theoretical Background}

Many more notions of sustainable development have been elaborated by many international institutions and organizations including experts and economists. The UN-sponsored World Commission on Environment and Development (WCED) (also known as the Brundtland Commission), Our Common Future, holds the key statement of sustainable development, which defined it as 'development that meets the needs of the present without compromising the ability of future generations to meet their own needs' (Mebratu, 1998).

The term 'sustainable development' as defined by the Earth Summit held in Brazil in June 1992 is 'the realization of the right to development' (Muschett, 1996).

The United Nation's International Conference held in Copenhagen in 1995 had adopted a broader vision of development (politically, economically, ethically, and spiritually) based on human dignity, rights, equality, peace, democracy, and 
full respect for various religious and ethical values and different peoples' cultural backgrounds which go against this vision (Angus, 1995).

Pezzey (1992) defines 'sustainable development' as 'an individual's benefit not lowered for a thousand years to come. This definition was based on the notion of 'benefit' that never gets low over a long period of time'.

Barbier and Markandya (1990) also stated that sustainable development is to 'preserve equal opportunities to the coming generations. This means that current resources do not belong to the current generation, but they belong to the coming ones so that the present generation cannot act as a drain on all available resources.

Sustainable development aims to achieve many objectives, the most important of which are: achievement of a better quality of life for all people, promotion of people's awareness of current environmental problems, respect for the natural environment, achievement of optimum investment and utilization of resources, linking the community's objectives to modern technology, effecting real change in the community's needs and priorities, and achievement of a constant and balanced economic and technical growth.

Earth Summit's sustainable development committee published a book on sustainable development indicators (130 in number) divided into four major categories or dimensions: economic, social, environmental, and technological or institutional (Dodds, 2014; Gennar, 2007).

\section{Statistical Analysis of Data}

\subsection{Reality of Sustainable Development in Yemen during the Period 2000-2018}

In 2015, United Nations Member States approved the Sustainable Development Goals (SDGs). These goals, also termed Global Goals, are: advocacy and action to end poverty, protection of our planet, and the ensuring of peace and prosperity for mankind by the year 2030. As stated by the sustainable 
development's seventeen goals, development should create balance among economic, social, and environmental sustainability. 1

This section will show the key indicators of sustainable development in Yemen during the period 2000-2018. They are economic, social, environmental, and institutional or technological indicators (Braus \& Wood, 1993).

\subsubsection{Economic Dimension Indicators of Sustainable Development in Yemen}

Table 1 shows the progression of many economic indicators of sustainable development's in Yemen during the period 2000-2018, which varied considerably, some changing for the better, and some for the worse. The table contains indicators such as GDP per capita, ratio of exports to imports, public debt to GDP, gross fixed capital formation to $\mathrm{GNI}$, and official development assistance to GDP, economic growth rate, and per capita energy use rate.

Table 1: Indicators of the Economic Dimension of Sustainable Development in Yemen (2000-2018)

\begin{tabular}{|l|c|c|c|c|c|c|c|}
\hline Year & $\begin{array}{c}\text { Per } \\
\text { capita } \\
\text { GDP }\end{array}$ & $\begin{array}{c}\text { Export } \\
\text { to } \\
\text { imports }\end{array}$ & $\begin{array}{c}\text { Debt to } \\
\text { GDP }\end{array}$ & $\begin{array}{c}\text { Cross Capital } \\
\text { formation \% } \\
\text { of GDP }\end{array}$ & $\begin{array}{c}\text { Net ODA } \\
\text { received (\% of } \\
\text { GNI) }\end{array}$ & $\begin{array}{c}\text { Growth } \\
\text { rate }\end{array}$ & $\begin{array}{c}\text { Per capita } \\
\text { energy } \\
\text { use }\end{array}$ \\
\hline $\begin{array}{l}2000- \\
2003\end{array}$ & 1184.28 & 1.300 & 59.02 & 18.32 & 3.1 & 4.42 & 285.41 \\
\hline $\begin{array}{l}2004- \\
2007\end{array}$ & 1238.65 & 0.996 & 44.28 & 18.96 & 1.7 & 4.02 & 327.32 \\
\hline $\begin{array}{l}2008- \\
2011\end{array}$ & 1251.10 & 0.690 & 43.59 & 23.53 & 2.2 & 0.63 & 326.65 \\
\hline $\begin{array}{l}2012- \\
2015\end{array}$ & 1046.13 & 0.360 & 50.32 & 24.79 & 2.3 & -5.24 & 286.59 \\
\hline $\begin{array}{l}2016- \\
2018\end{array}$ & 656.77 & 0.048 & 74.74 & 16.01 & 2.3 & -4.56 & 242.57 \\
\hline
\end{tabular}

Source: Supplied by the researcher based on data of statistical yearbook (2003-2018), Central Statistical Organization of Yemen, and World Bank's database https://data.worldbank.org/

\footnotetext{
1 https://sdgs.un.org/goals
} 


\subsubsection{Social Dimension Indicators of Sustainable Development in Yemen}

There are many social indicators of sustainable development in Yemen. The most notable ones are: unemployment rate, population growth rate, life expectancy at birth, high school enrollment rate, rate of mortality in children under five years of age (per 1,000 live births), and expenditure on health (\% of GDP). See table 2:

Table 2: Indicators of the Social Dimension of Sustainable Development in Yemen (2000-2018)

\begin{tabular}{|l|c|c|c|c|c|c|}
\hline Year & $\begin{array}{c}\text { Unemployment } \\
\text { rate }\end{array}$ & $\begin{array}{c}\text { The } \\
\text { population } \\
\text { growth } \\
\text { rate }\end{array}$ & $\begin{array}{c}\text { Life } \\
\text { expectancy } \\
\text { at } \\
\text { birth }\end{array}$ & $\begin{array}{c}\text { High } \\
\text { school } \\
\text { enrollment } \\
\text { rate }\end{array}$ & $\begin{array}{c}\text { Mortality } \\
\text { rate, under-5 } \\
\text { (per 1,000 } \\
\text { live births) }\end{array}$ & $\begin{array}{c}\text { Expenditure } \\
\text { on health (\% } \\
\text { of GDP) }\end{array}$ \\
\hline $\begin{array}{l}2000- \\
2003\end{array}$ & 11.68 & 2.93 & 61.51 & 51.51 & 87.73 & 5.05 \\
\hline $\begin{array}{l}2004- \\
2007\end{array}$ & 12.11 & 2.89 & 63.72 & 36.82 & 70.38 & 5.52 \\
\hline $\begin{array}{l}2008- \\
2011\end{array}$ & 12.70 & 2.85 & 65.37 & 33.84 & 57.53 & 5.42 \\
\hline $\begin{array}{l}2012- \\
1025\end{array}$ & 13.39 & 2.72 & 66.02 & 39.61 & 55.58 & 4.81 \\
\hline $\begin{array}{l}2016- \\
2018\end{array}$ & 13.15 & 2.43 & 66.09 & 41.63 & 57.43 & 3.62 \\
\hline
\end{tabular}

Source: Supplied by the researcher based on data of statistical yearbook (2003-2018), Central Statistical Organization of Yemen, and World Bank's database https://data.worldbank.org/

\subsubsection{Environmental Dimension Indicators of Sustainable Development in Yemen}

Notable decline was observed in the environmental dimension indicators of sustainable development in Yemen due to the growing population which has led to a decrease in agricultural land per capita and the lack of change in the land area because of its limitation, the increased emissions of carbon dioxide $\left(\mathrm{CO}_{2}\right)$, smoke asphyxiation of cities, and the decline in the proportion of agricultural lands to the total land due to deforestation, growing urbanization, and low investment in the agricultural sector. Table 3 shows the change in the environmental dimension indicators of sustainable development in Yemen during the period 2000-2018. 
Table 3: Indicators of the Environmental Dimension of Sustainable Development in Yemen (2000-2018)

\begin{tabular}{|l|c|c|c|c|}
\hline Year & $\begin{array}{c}\text { Agricultural area per } \\
\text { capita (hectares) }\end{array}$ & $\begin{array}{c}\text { Fertilizer use,( kg per } \\
\text { hectare of arable land) }\end{array}$ & $\begin{array}{c}\text { CO2 } \\
\text { emissions } \\
\text { (kt) }\end{array}$ & $\begin{array}{c}\text { Agricultural land } \\
\text { (\% of land area) }\end{array}$ \\
\hline $\begin{array}{l}2000- \\
2003\end{array}$ & 0.0130 & 7.30 & 15979.9 & 44.71 \\
\hline $\begin{array}{l}2004- \\
2007\end{array}$ & 0.0116 & 14.33 & 20303.3 & 44.67 \\
\hline $\begin{array}{l}2008- \\
2011\end{array}$ & 0.0103 & 14.54 & 22737.2 & 44.51 \\
\hline $\begin{array}{l}2012- \\
2015\end{array}$ & 0.0092 & 18.83 & 20507.7 & 44.60 \\
\hline $\begin{array}{l}2016- \\
2018\end{array}$ & 0.0084 & 15.83 & 7818.6 & 44.60 \\
\hline
\end{tabular}

Source: Supplied by the researcher based on data of statistical yearbook (2003-2018), Central Statistical Organization of Yemen, and World Bank's database https://data.worldbank.org/

\subsubsection{Institutional Dimension Indicators of Sustainable Development in Yemen}

Technology has played a great role in promoting mankind, particularly in the field of information technology and communication. Thus, it has also improved the performance of non-governmental institutions and promoted research activities, besides its contribution to modernizing all types of institutions which utilize technology to stimulate economic growth, create job opportunities for young people, and reduce poverty and unemployment in societies. These institutions play an important part in different areas of development. They help transform society into an information society thus achieving the desired objectives of technology in the area of sustainable development. The internet, as a technological facility, plays a major role in providing information.

These indicators were impressive during the period 2000-2018, thus resulting in the acceleration of the pace of sustainable development in the institutional dimension. See table 4: 
Table 4: Indicators of the Institutional Dimension of Sustainable Development in Yemen (2000-2018)

\begin{tabular}{|l|c|c|c|c|}
\hline Year & $\begin{array}{c}\text { Scientific } \\
\text { and technical } \\
\text { journal articles }\end{array}$ & $\begin{array}{c}\text { Mobile cellular } \\
\text { subscriptions (per 100 } \\
\text { people) }\end{array}$ & $\begin{array}{c}\text { Internet } \\
\text { users per } \\
\mathbf{1 , 0 0 0} \text { people }\end{array}$ & $\begin{array}{c}\text { Landline phone } \\
\text { subscriptions (per } \\
\text { 100 people) }\end{array}$ \\
\hline $2000-2003$ & 31.50 & 1.80 & 0.32 & 2.74 \\
\hline $2004-2007$ & 47.25 & 13.43 & 2.05 & 4.51 \\
\hline $2008-2011$ & 88.25 & 40.81 & 11.03 & 4.46 \\
\hline $2012-2015$ & 118.25 & 61.67 & 21.02 & 4.47 \\
\hline $2016-2018$ & 127.67 & 56.45 & 25.21 & 4.26 \\
\hline
\end{tabular}

Source: Supplied by the researcher based on data of statistical yearbook (2003-2018), Central Statistical Organization of Yemen, and World Bank's database https://data.worldbank.org/

Upon demonstration of the previous indicators of sustainable development in Yemen, one can conclude that, despite improvement in some periods, these indicators, particularly in the period 2016-2018, were greatly affected by the political upheavals and civil wars in Yemen starting in 2015.

\subsection{Reality of Small and Medium-Sized Enterprises in Yemen during 2000-2018}

\subsubsection{Definition of Small and Medium-Sized Enterprises and Their Place in Private Industrial Sector}

The Ministerial Decree no. 631 of 2009 divided establishments into categories including large establishments, medium-sized establishments, small and smaller establishments, according to two criteria: workforce and capital. Table 5 shows the division of establishments in accordance with size.

Table 5: Division of Enterprises in Yemen According to Size

\begin{tabular}{|l|c|c|c|c|}
\hline Statement & $\begin{array}{c}\text { Smaller } \\
\text { establishments }\end{array}$ & $\begin{array}{c}\text { Small } \\
\text { establishments }\end{array}$ & $\begin{array}{c}\text { Medium } \\
\text { establishments }\end{array}$ & $\begin{array}{c}\text { Large } \\
\text { establishments }\end{array}$ \\
\hline Capital $(\$)^{*}$ & $5000>$ & $5000-100,000$ & $100,000-500,000>$ & $500,000<$ \\
\hline Number of workers & $1-3$ & $4-9$ & $10-50$ & $50<$ \\
\hline
\end{tabular}

Source: Ministry of Industry and Trade (2015), Manual of small, medium-sized, and micro-projects: German Agency for International Cooperation (GIZ), June, Yemen, Sana'a. Note: *In 2009, 1\$ was worth YR 200. 
Small and medium-sized enterprises have their unique place in economic activity; they fight against unemployment and generate income and the valueadded. The role they play in economic activity, of course, constitutes the largest percentage of the private industrial sector. Table 6 shows the proportion of the contribution of both small and medium-sized enterprises to employment during the period 2016-2018.

Table 6: Number of Employees in the Private Sector according to Size of Establishment during the Period (2016-2018)

\begin{tabular}{|l|c|c|c|c|c|c|}
\hline \multirow{2}{*}{ Establishment by Size } & \multicolumn{5}{|c|}{ Total of Employees } \\
\cline { 2 - 7 } & \multicolumn{2}{|c|}{$\mathbf{2 0 1 6}$} & \multicolumn{2}{c|}{$\mathbf{2 0 1 7}$} & \multicolumn{2}{c|}{$\mathbf{2 0 1 8}$} \\
\cline { 2 - 7 } & No. & \% & No. & \% & No. & \% \\
\hline Small & 82295 & 44.5 & 82659 & 44.5 & 86730 & 44.5 \\
\hline Medium & 35952 & 19.5 & 36112 & 19.5 & 37890 & 19.5 \\
\hline Large & 66582 & 36.0 & 66876 & 36.0 & 70169 & 36.0 \\
\hline Total & 184829 & 100 & 185647 & 100 & 194788.7 & 100 \\
\hline
\end{tabular}

Source: Statistical Yearbook, (2018). Central Statistical Organization, Yemen.

As shown in table 6, small enterprises occupy the first position in terms of employment which reaches $44 \%$. Then, large enterprises come to occupy the second position at $36 \%$. The third position is occupied by medium-sized enterprises at $19.5 \%$. Small and medium-sized enterprises constitute $64 \%$ of total employment in the industrial private sector. They greatly contribute to incomegenerating as shown in table 7 :

Table 7: Compensations for Employees in the Private Sector by Size of Establishment (2016 - 2018)

\begin{tabular}{|l|c|c|c|c|c|c|}
\hline \multirow{2}{*}{$\begin{array}{l}\text { Establishment } \\
\text { by Size }\end{array}$} & \multicolumn{5}{|c|}{ Total of Employees' Compensations / Million dollars } \\
\cline { 2 - 7 } & \multicolumn{2}{|c|}{$\mathbf{2 0 1 6}$} & \multicolumn{2}{c|}{$\mathbf{2 0 1 7}$} & \multicolumn{2}{c|}{$\mathbf{2 0 1 8}$} \\
\cline { 2 - 7 } & Compensation & \% & Compensation & \% & Compensation & \% \\
\hline Small & 41.9 & 21.3 & 42.0 & 21.3 & 44.1 & 21.3 \\
\hline Medium & 28.4 & 14.4 & 28.5 & 14.4 & 29.9 & 14.4 \\
\hline Large & 126.4 & 64.3 & 126.9 & 64.3 & 133.2 & 64.3 \\
\hline Total & 196.7 & 100 & 197.4 & 100 & 207.2 & 100 \\
\hline
\end{tabular}

Source: Statistical Yearbook, (2018). Central Statistical Organization, Yemen. Note: In 2016, $1 \$$ was worth YR 280.4 
As table 7 shows, large enterprises occupy the first position in terms of employees' compensation which reaches $64.3 \%$. Then, small enterprises come to occupy the second position at $21.3 \%$. The third position is occupied by mediumsized enterprises at $14.4 \%$. Small and medium-sized enterprises constitute $35.7 \%$ of the total compensation for employees of the industrial private sector. The contribution of small and medium-sized enterprises to the gross production value of the private sector's industrial establishments can be shown in table 8:

Table 8: Gross Production Value of Industrial Establishments by Size (Private Sector) during the Period (2016-2018)

\begin{tabular}{|l|c|c|c|c|c|c|}
\hline \multirow{3}{*}{$\begin{array}{l}\text { Establishment } \\
\text { by Size }\end{array}$} & \multicolumn{5}{|c|}{$\begin{array}{c}\text { Gross Production Value of Industrial Establishments by } \\
\text { Size (Private Sector): 2016- 2018 /Million dollars }\end{array}$} \\
\cline { 2 - 7 } & \multicolumn{2}{|c|}{$\mathbf{2 0 1 6}$} & \multicolumn{2}{c|}{$\mathbf{2 0 1 7}$} & \multicolumn{2}{c|}{$\mathbf{2 0 1 8}$} \\
\cline { 2 - 7 } & Value & \% & Value & \% & Value & $\%$ \\
\hline Small & 1622.9 & 28.4 & 1620.7 & 28.4 & 1702.9 & 28.4 \\
\hline Medium & 364.4 & 6.4 & 363.9 & 6.4 & 382.3 & 6.4 \\
\hline Large & 3734.9 & 65.3 & 3729.8 & 65.3 & 3918.9 & 65.3 \\
\hline Total & 5722.1 & 100 & 5714.4 & 100 & 6004.0 & 100 \\
\hline
\end{tabular}

Source: Statistical Yearbook, (2018). Central Statistical Organization, Yemen.

It is obvious from table 8 that large enterprises occupy the first position in terms of gross production value which reaches $64.3 \%$. Then, small enterprises occupy the second position at $28.4 \%$. The third position is occupied by mediumsized enterprises at $6.4 \%$. Small and medium-sized enterprises constitute $34.8 \%$ of the gross production value of the industrial private sector. Table 9 shows the value-added generated by small and medium-sized enterprises and the ratio of contribution to gross value added of private sector's industrial enterprises.

Table 9: Gross Value- Added of Industrial Establishments by Size (Private Sector) during the Period (2016-2018)

\begin{tabular}{|l|c|c|c|c|c|c|}
\hline \multirow{2}{*}{$\begin{array}{l}\text { Establishment } \\
\text { by Size }\end{array}$} & \multicolumn{5}{|c|}{$\begin{array}{c}\text { Gross Value-Added of Industrial Establishments by } \\
\text { Size (Private Sector): 2016- 2018/ Million dollars }\end{array}$} \\
\cline { 2 - 7 } & \multicolumn{2}{|c|}{$\mathbf{2 0 1 6}$} & \multicolumn{2}{c|}{$\mathbf{2 0 1 7}$} & \multicolumn{2}{c|}{$\mathbf{2 0 1 8}$} \\
\cline { 2 - 7 } & Value & \% & Value & \% & Value & $\%$ \\
\hline Small & 639.3 & 32.4 & 619.9 & 31.5 & 628.1 & 29.4 \\
\hline Medium & 154.1 & 7.8 & 147.3 & 7.5 & 133.8 & 6.3 \\
\hline Large & 1177.2 & 59.7 & 1201.2 & 61.0 & 1371.6 & 64.3 \\
\hline Total & 1970.6 & 100 & 1968.5 & 100 & 2133.5 & 100 \\
\hline
\end{tabular}

Source: Statistical Yearbook, (2018). Central Statistical Organization, Yemen. 
Table 9 shows that large enterprises occupy the first position in terms of gross value added which reaches $64.3 \%$. Then, small enterprises occupy the second position at $29.4 \%$. The third position is occupied by medium-sized enterprises at 6.3\%. Small and medium-sized enterprises constitute $35.7 \%$ of the gross value added of the industrial private sector. Regarding the contribution of small and medium-sized enterprises of private sector's industrial establishments, it can be noted that their contribution to occupancy, income-generating, production, and value-added is $64 \%, 35.7 \%, 34.8 \%$, and $34.8 \%$ respectively.

Though small and medium-sized enterprises achieve a high rate of contribution to employment, they achieve a low rate of contribution to production. Ascribed to the declining productivity of laborers are the small size of these enterprises, their restriction to the family sector, poor performance of laborers, use of primitive production techniques, and the seasonality of some products, (especially those enterprises whose input depends on agricultural products).

\subsubsection{Development of SMEs in Yemen during the Period (2000-2018)}

This section discusses the development of small and medium-sized enterprises in Yemen during the period 2000-2018 in terms of numbers, number of workers employed, their productivity value, and the value-added. See table 10:

Table 10: Development of Small and Medium-Sized Enterprises during the Period (2000-2018)

\begin{tabular}{|l|c|c|c|c|c|c|c|c|}
\hline & \multicolumn{4}{|c|}{ Small Enterprises } & \multicolumn{4}{c|}{ Mid-size Enterprises } \\
\cline { 2 - 9 } Year & No. & $\begin{array}{c}\text { Number } \\
\text { of } \\
\text { workers }\end{array}$ & $\begin{array}{c}\text { Gross } \\
\text { production } \\
\text { value }\end{array}$ & $\begin{array}{c}\text { Gross } \\
\text { value } \\
\text { added }\end{array}$ & No. & $\begin{array}{c}\text { Number } \\
\text { of } \\
\text { workers }\end{array}$ & $\begin{array}{c}\text { Gross } \\
\text { production } \\
\text { value }^{*}\end{array}$ & $\begin{array}{c}\text { Gross } \\
\text { value } \\
\text { added }^{*}\end{array}$ \\
\hline $\begin{array}{l}2000- \\
2003\end{array}$ & 27228 & 64960 & 284.54 & 121.03 & 1905 & 11470 & 61.83 & 29.32 \\
\hline $\begin{array}{l}2004- \\
2007\end{array}$ & 37991 & 93753 & 1077.88 & 369.43 & 3707 & 26007 & 244.83 & 96.67 \\
\hline $\begin{array}{l}2008- \\
2011\end{array}$ & 41053 & 84997 & 2450.60 & 918.26 & 4321 & 29989 & 456.53 & 178.75 \\
\hline $\begin{array}{l}2011- \\
2015\end{array}$ & 56239 & 138726 & 2818.74 & 1179.05 & 6404 & 47332 & 638.79 & 294.44 \\
\hline
\end{tabular}




\begin{tabular}{|l|l|l|l|l|l|l|l|l|}
\hline $\begin{array}{l}2016- \\
2018\end{array}$ & 33327 & 83895 & 1340.07 & 489.54 & 5087 & 36651 & 286.34 & 114.07 \\
\hline
\end{tabular}

Source: Statistical Yearbook, (2018). Central Statistical Organization, Yemen. http://cso-yemen.com/

Comprehensive Industrial Survey (2005-2008), Central Statistical Organization, Yemen. http://cso-yemen.com/ Ministry of Industry and Trade (2015), Manual of small, medium-sized, and micro projects: German Agency for international Cooperation (GIZ), June, Yemen, Sana'a.

Note: * \$ One million.

Table 10 shows that small and medium-sized enterprises continued to increase in number, in the number of their workers, their gross production, and their gross value-added, except for the period 2016-2018 during which they suffered a clear decline due to wars and political unrest in Yemen.

\subsubsection{SMEs Relative Importance in Industrial Sector and Economy as a whole}

\subsubsection{Relative Importance of Small Enterprises}

Table 11 below shows the relative importance of small enterprises in the industrial sector and the economy as a whole through their employment rate to the industrial sector and economy as a whole, the rate of productivity to the productivity rate of the industrial sector, and the economy as a whole, and the value-added as a percentage of the value-added of the industrial sector and the value-added of the whole economy during the period 2000-2018.

Table 11: SMEs Relative Importance in Industrial Sector and Economy as a Whole (2000-2018)

\begin{tabular}{|l|c|c|c|c|c|c|}
\hline \multicolumn{7}{|c|}{ Small Enterprises } \\
\hline Year & $\begin{array}{c}\text { Employment } \\
\text { Rate \% } \\
\text { of total } \\
\text { Employment }\end{array}$ & $\begin{array}{c}\text { Employment } \\
\text { Rate } \\
\% \text { of } \\
\text { Employment } \\
\text { in industrial } \\
\text { sector }\end{array}$ & $\begin{array}{c}\text { Productivity } \\
\% \text { GDP }\end{array}$ & $\begin{array}{c}\text { Productivity } \\
\text { \% of } \\
\text { industrial } \\
\text { sector's } \\
\text { productivity }\end{array}$ & $\begin{array}{c}\text { Value } \\
\text { Added \% } \\
\text { of gross } \\
\text { value } \\
\text { added }\end{array}$ & $\begin{array}{c}\text { Value Added } \\
\% \text { of Value } \\
\text { Added of } \\
\text { industrial } \\
\text { sector }\end{array}$ \\
\hline $\begin{array}{l}2000- \\
2003\end{array}$ & 1.75 & 11.63 & 2.44 & 4.99 & 1.14 & 2.42 \\
\hline $\begin{array}{l}2004- \\
2007\end{array}$ & 2.30 & 13.53 & 4.87 & 6.43 & 1.88 & 4.63 \\
\hline $\begin{array}{l}2008- \\
2011\end{array}$ & 1.89 & 10.51 & 8.16 & 11.17 & 3.57 & 9.24 \\
\hline
\end{tabular}




\begin{tabular}{|l|c|c|c|c|c|c|}
\hline $\begin{array}{l}2012- \\
2015\end{array}$ & 2.15 & 14.71 & 6.75 & 11.51 & 3.69 & 11.17 \\
\hline $\begin{array}{l}2016- \\
2018\end{array}$ & 1.53 & 14.31 & 9.10 & 20.69 & 4.90 & 20.91 \\
\hline
\end{tabular}

Source: Supplied by the researcher according to database of Central Statistical Organization of Yemen.

Official Data from the Ministry of Industry and Trade, Yemen

Database of The Statistical, Economic and Social Research and Training Centre for Islamic Countries (SESRIC). https:// www.sesric.org/oicstat-ar.php

As already indicated in table 11, there was progress in the contribution of small and medium-sized enterprises to employment, productivity, and valueadded during all periods. This progress in contribution continued to grow even during the period 2016-2018, despite the war and political upheaval in the country. The reason is that while GDP and the value-added of the industrial and economic sector as a whole suffered a decline, SMEs continued to improve.

\subsubsection{Relative Importance of Medium-sized Enterprises}

With reference to the contribution medium-sized enterprises to the economy, it can be noted that it is lower than that of small enterprises. However, it continued to grow from time to time, especially during the period 2016-2018. The reason for this can be related to the declining economic performance as a whole under war and political upheaval in the country. Added to this is that the contribution of medium-sized enterprises is a percentage of employment, GDP, and value-added of the industrial sector and the economy as a whole. The findings show that there is an increase in the rate of medium-sized enterprises' contribution to the economy. See table 12: 
Table 12: Relative Importance of Medium-Sized Enterprises in the Economy (2000-2018)

\begin{tabular}{|l|c|c|c|c|c|c|}
\hline \multicolumn{7}{|c|}{ Medium-sized Enterprises } \\
\hline Year & $\begin{array}{c}\text { Employment } \\
\text { Rate \% of total } \\
\text { Employment } \\
\text { \% of } \\
\text { Employment } \\
\text { in industrial } \\
\text { sector }\end{array}$ & $\begin{array}{c}\text { Productivity } \\
\% \text { GDP }\end{array}$ & $\begin{array}{c}\text { Productivity } \\
\text { \% of } \\
\text { industrial } \\
\text { sector's } \\
\text { productivity }\end{array}$ & $\begin{array}{c}\text { Value } \\
\text { Added } \\
\% \text { of gross } \\
\text { value } \\
\text { added }\end{array}$ & $\begin{array}{c}\text { Value Added } \\
\% \text { of Value } \\
\text { Added of } \\
\text { industrial } \\
\text { sector }\end{array}$ \\
\hline $\begin{array}{l}2000- \\
2003\end{array}$ & 0.31 & 2.02 & 0.51 & 1.01 & 0.27 & 0.56 \\
\hline $\begin{array}{l}2004- \\
2007\end{array}$ & 0.64 & 3.77 & 1.15 & 1.58 & 0.51 & 1.25 \\
\hline $\begin{array}{l}2008- \\
2011\end{array}$ & 0.67 & 3.70 & 1.51 & 2.09 & 0.70 & 1.77 \\
\hline $\begin{array}{l}2012- \\
2015\end{array}$ & 0.73 & 5.03 & 1.53 & 2.60 & 0.93 & 2.85 \\
\hline $\begin{array}{l}2016- \\
2018\end{array}$ & 0.67 & 4.27 & 1.92 & 4.36 & 1.13 & 4.83 \\
\hline
\end{tabular}

Source: Supplied by the researcher according to database of Central Statistical Organization of Yemen.

Official Data from the Ministry of Industry and Trade, Yemen of the Statistical, Economic and Social Research and Training Centre for Islamic Countries (SESRIC). https://www.sesric.org/oicstat-ar.php

Referring to the contribution of small and medium-sized enterprises during the period 2000-2018, it can be noted that the contribution of small enterprises is greater than that of medium- sized enterprises in terms of employment, productivity, and value-added. It is also noted that small and medium- sized enterprises could favorably continue contributing to the economy under war circumstances in Yemen. This reflects the importance of these enterprises which should be encouraged and provided with all facilities they need for survival.

\section{Empirical Analysis of Data}

\subsection{Hypothesis}

Taking the problem and objectives of this study as its basis, this research seeks to examine the following null hypotheses:

- HO: No significant relationship exists between small enterprises and sustainable development.

- HO: No significant relationship exists between medium-sized enterprises and sustainable development. 
- Ho: No significant relationship exists between small and medium-sized enterprises (SMEs) and sustainable development.

\subsection{Methodology}

To analyze data, this study uses the partial least squares structural equation modeling (PLS- SEM) and SmartPIS3 program (Ringle, Da Silva, \& Bido, 2015) This section includes the results of structural analysis of structural relationships aiming to examine the interrelationship between SMEs, as a latent independent variable, and sustainable development (D), as a latent dependent variable. For this purpose, an exploratory model was adopted to identify the impact of SMEs on sustainable development in Yemen during the period 2000-2018.

\subsection{Definition of Independent and Dependent Variables}

\section{Independent Variables}

Small and medium-sized enterprises (SME):

Small enterprises (SE) with their indicators:

- Number of small enterprises (SEN)

- Number of employees (SENOE)

- Value of production (SEVP)

- Value-added (SEVA)

Medium enterprises (ME) with their indicators:

- Number of medium enterprises (MEN)

- Number of employees (MENOE)

- Value of production (MEVP)

- Value-added (MEVA)

\section{Dependent Variables}

Sustainable development $(D)$ with its four dimensions:

Economic dimension (ED) with its indicator:

- GDP per capita (EDGDPPC)

- Ratio of exports to imports (EDREI) 
- Ratio of public debt to GDP (EDRPD)

- Gross fixed capital formation (\% of GDP) (EDGFCF)

- Official development assistance (ODA) \% of GDP (EDODA)

- GDP growth rate (EDGR)

- Energy use (kg of oil equivalent per capita) (EDEUPC)

Social dimension (SD) with its indicator:

- Unemployment (SDUE)

- Population growth rate (SDPGR)

- Life expectancy at birth (SDLEB)

- High school enrollment rate (SDHSE)

- Mortality rate, under-5 (per 1,000 live births) (SDMRUF)

- Health expenditure

- Expenditure (\% of GDP) (SDHE)

Environmental dimension (END) with its indicators:

- Agricultural land area per capita (hectares per person) (ENDALPR)

- Fertilizer consumption (kilograms per hectare of arable land) (ENDFC)

- CO2 emissions (kt) (ENDCOTE)

- Agricultural land (\% of arable land) (ENDALA)

Institutional dimension (ID) with its indicators:

- Scientific and technical journal articles (IDSTJA)

- Mobile cellular subscriptions (per 100 people) (IDMCS)

- Internet users (per 1,000 people) (IDIU)

- Fixed telephone subscriptions (per 100 people) (IDFTS)

\subsection{General Structural Model of Study Variables'}

Figure 1, below, shows the general structural model of study variables. The model parameters are determined according to partial least squares structural equation modeling (PLS-SEM) and SmartPIS3 program. ${ }^{2}$

2 https://www.smartpls.com/ 
Figure 1. SmartPIS.3 Program's Outcomes

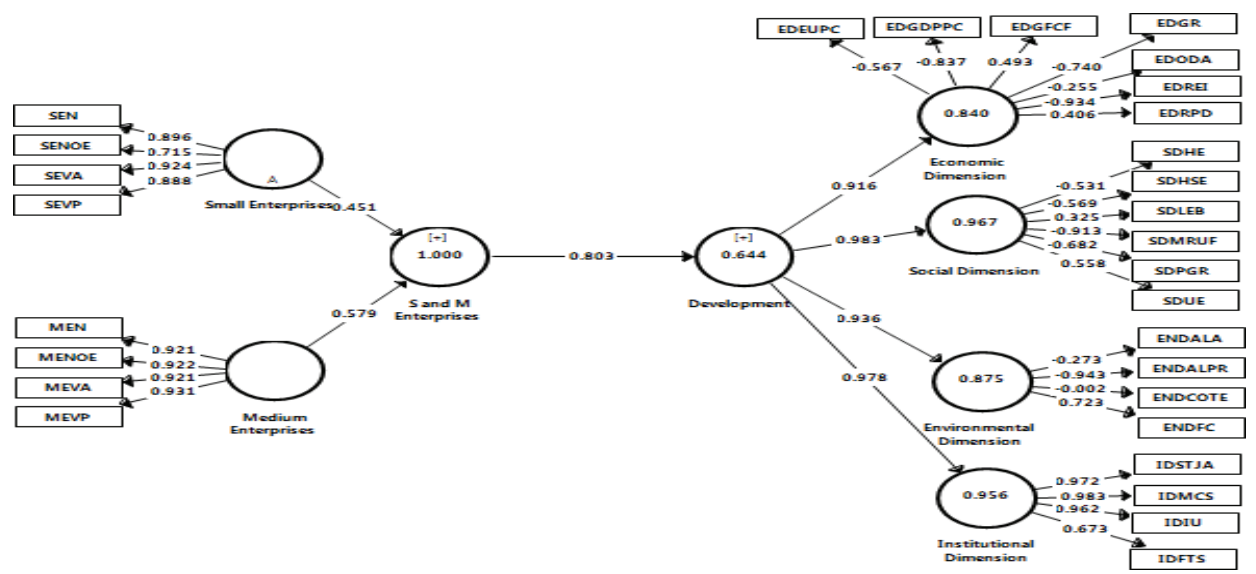

As figure 1 shows, all outer loadings of measured indicators of exogenous latent variables represented by small and medium-sized enterprises were statistically acceptable since they had exceeded the minimum of 0.5 . rho_A scale affiliated to both small and medium-sized enterprises as well as medium-sized and small enterprises reached $0.95,0.94$, and 0.90 , respectively, 'thus exceeding the minimum of 0.7 indicating that all measured indicators used to represent independent variables were homogeneous. (Hair, Sarstedt, Ringle, and Gudergan, 2017).

However, outer loadings of measured indicators of endogenous latent variables represented by the four dimensions of sustainable development were low and thus retained at this point in order to improve the model quality. (Hair Jr, Hult, Ringle, and Sarstedt, 2016). rho_A scale of sustainable development, economic dimension, social dimensions, environmental dimension, and institutional dimension were $0.95,0.73,0.72,0.83$, and 0.96 , respectively, thus exceeding the minimum of 0.7 . Outer loadings of some indicators were shown to have negative values, indicating that these indicators adversely impacted their dimensions, and do not make an effective contribution to sustainable development. This can be referred to as the poor planning of development in general and sustainable development programs, in particular. 


\subsection{Model of Direct Impact of Sustainable Development on the Four Dimensions}

Drawing on the general outline of the study variables structural model as shown in figure 1, the structural model of analyzing interrelationships between sustainable development, as a latent variable, and the four development dimensions, as latent variables, was determined. See table 13:

Table 13: Direct Impact of Sustainable Development on the Four Dimensions

\begin{tabular}{|l|c|c|c|c|}
\hline Paths & Path Coefficients & T Statistics & P Values & $\begin{array}{c}\text { R Square } \\
\text { Adjusted }\end{array}$ \\
\hline $\begin{array}{l}\text { Development -> Economic } \\
\text { Dimension }\end{array}$ & 0.916 & 76.142 & 0.000 & 0.83 \\
\hline $\begin{array}{l}\text { Development -> Environmental } \\
\text { Dimension }\end{array}$ & 0.936 & 74.577 & 0.000 & 0.87 \\
\hline $\begin{array}{l}\text { Development -> Institutional } \\
\text { Dimension }\end{array}$ & 0.978 & 1.761 & 0.044 & 0.95 \\
\hline Development -> Social Dimension & 0.983 & 53.697 & 0.000 & 0.96 \\
\hline
\end{tabular}

Source: Findings of statistical data based on Smartpls program.

As table 13 shows, a direct correlation exists between sustainable development, as an inclusive variable, and its four dimensions (economic, social, environmental, and institutional). In that, all path coefficients are between $0-1$, and they are statistically significant according to the T-test of the model parameters, reaching less than P-Value $=0.05$. It is also noted that all values of $\mathrm{R}$ Square Adjusted were within their scope defined by $0-1$ (Brians, 2016).

\subsection{Model of Indirect Impact of Small and Medium-sized Enterprises on Sustainable Development's Four Dimensions}

Table 14: Model of Indirect Impact of Small and Medium-sized Enterprises on Sustainable Development's Four Dimensions

\begin{tabular}{|l|c|c|c|c|}
\hline Paths & Path Coefficients & T Statistics & P Values & R Square Adjusted \\
\hline SME -> Economic Dimension & 0.735 & 1.754 & 0.045 & 0.830 \\
\hline SME -> Environmental Dimension & 0.751 & 1.778 & 0.042 & 0.870 \\
\hline SME -> Institutional Dimension & 0.785 & 9.265 & 0.000 & 0.950 \\
\hline SME -> Social Dimension & 0.789 & 1.810 & 0.040 & 0.960 \\
\hline
\end{tabular}

Source: Findings of statistical data based on Smartpls program. 
It is noted from table 14 that a direct correlation exists between small and medium-sized enterprises, as an independent inclusive variable, and sustainable development's four dimensions. In that, all path coefficients are between 0-1, and they are statistically significant according to the T-test of the model parameters, and are reaching less than $\mathrm{P}-\mathrm{V}$ alue $=0.05$. It is also noted that all values of $\mathrm{R}$ Square Adjusted were within their scope defined by $0-1$.

\subsection{Model of Overall Impact of Small and Medium-sized Enterprises on Sustainable Development in its Four Dimensions}

Table 15 shows the overall impact of small and medium-sized enterprises separately on sustainable development in its four dimensions, and the overall impact of small and medium- sized enterprises, as an inclusive variable on sustainable development.

Table 15: Model of Overall Impact of SMEs on Sustainable Development in its Four Dimensions

\begin{tabular}{|l|c|c|c|c|}
\hline Paths & $\begin{array}{c}\text { Path } \\
\text { Coefficients }\end{array}$ & $\begin{array}{c}\text { T } \\
\text { Statistics }\end{array}$ & $\begin{array}{c}\text { P } \\
\text { Values }\end{array}$ & $\begin{array}{c}\text { R Square } \\
\text { Adjusted }\end{array}$ \\
\hline Small Enterprises -> Sustainable development & 0.362 & 1.771 & 0.043 & -- \\
\hline Medium Enterprises -> Sustainable development & 0.465 & 1.786 & 0.042 & -- \\
\hline S and M Enterprises -> Sustainable development & 0.803 & 1.775 & 0.043 & 0.644 \\
\hline
\end{tabular}

Source: Findings of statistical data based on Smartpls program.

To test the study hypotheses according to table 15 , three models can be created as follows:

Relationship Structural Model between Small Enterprises and Sustainable Development

$$
\begin{gathered}
D=0.362 S E+\varepsilon \ldots \\
S D=0.205 \quad T=1.77 \quad P=0.043
\end{gathered}
$$

Since Path Coefficients have a value of 0.362 and are statistically significant with a $\mathrm{p}$-value of 0.043 , it indicates that there is a relationship between small enterprises and sustainable development. Thus, we reject the view that denies the existence of a relationship between small enterprises and sustainable development. 
Relationship Structural Model between Medium-sized Enterprises and Sustainable Development

$$
\begin{gathered}
D=0.465 M E+\varepsilon \ldots \\
S D=0.260 \quad T=1.786 \quad P=0.042
\end{gathered}
$$

Since Path Coefficients have a value of 0.465 and are statistically significant with a p-value of 0.043 , we understand that there is a relationship between medium-sized enterprises and sustainable development. Thus, we reject the view that denies the existence of a relationship between medium-sized enterprises and sustainable development.

Relationship Structural Model between Small and Medium-sized Enterprises, as an Inclusive Independent Variable, and Sustainable Development, as Dependent Variable

$$
\begin{gathered}
D=0.803 S M E+\varepsilon \ldots \\
S D=0.452 T=1.775 \quad P=0.043 R^{2}=0.64
\end{gathered}
$$

From the previous structural model that shows the relationship between small and medium-sized enterprises, as an independent latent variable, and sustainable development, as a dependent latent variable, we can understand that a direct relationship exists between small and medium-sized enterprises and sustainable development in which Path Coefficients reach 0.803 and are statistically significant with a $p$-value of 0.043 , according to T-test of the model parameters. However, this value is below the approved level of comparison (0.05). Small and mediumsized enterprises affect sustainable development by 0.64 percent, according to $R$ Square Adjusted. The value 0.36 refers to other factors not included in the model.

\subsection{Structural Model Identification}

Indicators of structural model identification, according to partial least square equation, show the degree to which data is identical with the previous pilot model that demonstrates the impact of small and medium-sized enterprises on 
sustainable development. The present study approved the key indicators of identification shown in table 16:

Table 16: Key Indicators of Structural Model Identification

\begin{tabular}{|l|c|c|}
\hline Indicators & Range & Value \\
\hline $\mathrm{Q}^{2}$ & $0<$ & 0.25 \\
\hline GOF & $0-1$ & 0.72 \\
\hline SRMR & $0-1$ & 0.28 \\
\hline
\end{tabular}

Source: Supplied by the researcher based on analysis results

Table 16, on which the key measurable indicators are displayed, shows that the study pilot structural model is identical with data as shown by measurable indicators (Predictive relevance) $Q^{2}-$ (The Goodness of Fit) GOF- and Standardized root mean squared residual (SRMR) whose values are more than the level required. The value of indicator $Q^{2}$ reached 0.25 , thus exceeding 0.0. This demonstrates that independent indicators have a high predictive ability represented by the role of small and medium-sized enterprises in sustainable development as an endogenous latent variable with its dimensions (economic, social, environmental, and institutional). GOF was maintained at as high as 0.72 , thus exceeding the minimum of 0.1 (Wetzels, Odekerken-Schröder, and Van Oppen, 2009). Standardized root means squared residual (SRMR) was maintained at as less than 1 as 0.28 . Depending on the previous measurable indicators, it is safe to say that the structural model suggested for this study enjoys a high degree of approval when used properly to predict variables of sustainable development.

\section{Conclusion and Discussion}

Upon demonstrating the impact of small and medium-sized enterprises on sustainable development, it can be concluded that indicators of sustainable development, with its economic, social, environmental, and institutional dimensions, were exceedingly low and that they have been declining steadily in the last years due to the political turmoil that Yemen has been experiencing since 2011 and to the civil war that started early in 2015. All this led Yemen to be weak to attract foreign investors of large businesses, except for a minor part of the oil 
and gas sector. The problem came as a consequence of a neglect enacting laws and discouragement of investment. Added to this, the poor infrastructure has almost entirely been ruined in recent years as a result of the war. Such a declining situation in Yemen opened a viable gate for small and medium-sized enterprises to play a great part in the country's economy. Though they represent the greatest percentage of all projects, these enterprises still have a very low share of contribution to occupancy, production, and value-added. This is due to laborers' declining productivity which can be ascribed to the small size of these enterprises, their restriction to the family sector, the poor performance of laborers, use of primitive production techniques, and the seasonality of some products (especially those enterprises whose input depends on agricultural products).

Taking for granted the great role played by these enterprises in the promotion of sustainable development, the government should take steps to harmonize its policies to legally facilitate, enhance, and develop these enterprises and provide them with the necessary infrastructure.

Governmental aid to these enterprises can be provided by establishing a special agency through which the due process of research required for the development of this sector can be achieved. In addition, this would encourage their products, grant access for them even to international markets, give advice to entrepreneurs, and provide laborers with proper training adequate to dealing with technology.

\footnotetext{
Ethics Committee Approval: xxxxxxx.

Peer-review: Externally peer-reviewed.

Author Contributions: Conception/Design of Study- S.S., E.G.; Data Acquisition- S.S., Data Analysis/Interpretation- S.S.; Drafting Manuscript- S.S.; Critical Revision of Manuscript- E.G.; Final Approval and Accountability- S.S., E.G.

Conflict of Interest: The authors have no conflict of interest to declare.

Grant Support: The authors declared that this study has received no financial support.
} 


\section{REFERENCES}

Angus, J. (1995). The united nations world summit for social development. Social Policy Journal of New Zealand, 3(4), 1-5.

Barbier, E. B., \& Markandya, A. (1990). The conditions for achieving environmentally sustainable development. European Economic Review, 34(2-3), 659-669.

Braus, J., \& Wood, D. (1993). Environmental education in the schools: Creating a program that works! (Vol. 2). Washington, USA: Peace Corps.

Brians, C. L. (2016). Empirical political analysis: Pearson new international edition coursesmart etextbook. New York, USA: Routledge.

Central Statistical Organization of Yemen http://cso-yemen.com/ Accessed 10 December 2020- 17 January 2021

Çatal, M. F. (2007). Bölgesel kalkınmada küçük ve orta boy işletmelerin (kobi) rolü. Atatürk Üniversitesi Sosyal Bilimler Enstitüsü Dergisi, 10(2), 333-352.

Dodds, F. (2014). Reforming the international institutions. In F. Dodds (Ed.). Earth Summit 2002 - A New Deal. London: Earthscan.

Gennar, P. (2007). Key indicators of sustainable development. 2nd Kyoto International Seminar on Sustainable Growth in the Asia-Pacific Region, Kyoto, Japan.

Gökçek, E., ve Karakaya, Ö. (2020, Temmuz/July). Ekonomik kalkınmada işletmelerin rolü. Kongre Başkanı / Chair (Serkan DiLEK), Kastamonu Üniversitesi, 68-73.

Hair Jr, J. F., Hult, G. T. M., Ringle, C. M., \& Sarstedt, M. (2016). A primer on partial least squares structural equation modeling (PLS-SEM). Sage Publications.

Hair Jr, J. F., Sarstedt, M., Ringle, C. M., \& Gudergan, S. P. (2017). Advanced issues in partial least squares structural equation modeling. Sage Publications.

Hallberg, K. (2000). A market-oriented strategy for small and medium scale enterprises (Vol. 63). World Bank Publications.

Mebratu, D. (1998). Sustainability and sustainable development: Historical and conceptual review. Environmental Impact Assessment Review, 18(6), 493-520.

Ministry of Industry \& Trade Database- Yemen https://moit.gov.ye/moit/ Accessed 18 December 2020 - 22 January 2021) The Sustainable Development Goals h t t p s: // w w w. u n . o r g / sustainabledevelopment/sustainable-development-goals/ Accessed 25 December 2020

Mukwena, R. (2016). Zambia at fifty years: What went right, what went wrong and wither to? A treatise of the country's socio-economic and political developments since independence. Partridge Africa. Retrieved from http://www.inderscience.com/storage/f681112109432175.pdf

Muschett, F. D. (1996). Principles of sustainable development. CRC Press.

Pezzey, J. (1992). Sustainability: An interdisciplinary guide. Environmental Values, 1(4), 321-362.

Ringle, C., Da Silva, D., \& Bido, D. (2015). Structural equation modeling with the SmartPLS. Brazilia Journal of Marketing, 13(2), 56-73. 
Safiriyu, A. M., \& Njogo, B. O. (2012). Impact of small and medium scale enterprises in the generation of employment in Lagos State. Kuwait Chapter of the Arabian Journal of Business and Management Review, 1(11), 107-141.

Sharafat, A. L. I., Rashid, H., \& Khan, M. A. (2014). The role of small and medium enterprises and poverty in Pakistan: An empirical analysis. Theoretical and Applied Economics, 18(4), 64-80.

Taiwo, M. A., Ayodeji, A. M., \& Yusuf, B. A. (2012). Impact of small and medium enterprises on economic growth and development. American Journal of Business and Management, 1(1), 18-22.

The OIC Statistics (OICStat) Database https://www.sesric.org/oicstat.php Accessed 25 December 2020 - 12 January 2021

Wetzels, M., Odekerken-Schröder, G., \& Van Oppen, C. (2009). Using PLS path modeling for assessing hierarchical construct models: Guidelines and empirical illustration. MIS Quarterly, 177-195.

World Bank's database https://data.worldbank.org/ Accessed 16 - 27 December 2020

Zaidan, R. (2006). Activating the role of small and medium industrial industries in the process of economic and social development in Syria. Damascus University. 